\title{
Synthesis and its DNA Detecting Ability of Fluorescent Modified $\beta$-cyclodextrins having Long Chain Connected by pyrene Unit
}

\author{
Noriaki MatsumURA', Masami KagaYA ${ }^{2}$, Yoshihiko Kondo ${ }^{1,3}$, \\ Youichi AKAGAMI ${ }^{2}$ and Fumio HAMADA ${ }^{1,3}$ \\ ${ }^{1}$ Department of Materials-Process Engineering and Applied Chemistry for Environments, \\ Faculty of Engineering and Resource Science, Akita University, Tegata, Akita 010-8502, Japan \\ ${ }^{2}$ Akita Prefectural Industrial Technology Center, 4-11, Arayamachi-Aza-Sanuki, Akita 010-1623, Japan \\ ${ }^{3}$ Department of Life Science, Faculty of Engineering and Resource Science, \\ Akita University, Tegata, Akita 010-8502, Japan \\ E-mail : hamada@ipc.akita-u.ac.jp
}

\begin{abstract}
Two kinds of pyrene modified $\beta$-cyclodextrins, which are different in linker parts to bind between $\beta$-cyclodextrin and pyrene unit, were synthesized. Those derivatives show different behavior for single and double strands of DNA, where short linker derivative shows no interaction for DNA, but longer linker derivative indicates there are something interaction for DNA by intercalating of pyrene unit.
\end{abstract}

Key Words : cyclodextrins, pyrene, ssDNA, dsDNA, linker, fluorescent spectra, linker

\section{INTRODUCTION}

Recently, a base and a particular disease sequences of DNA for human being have been studied and clarified. [1] Although, a lot of fluorescent substances are utilized to detect specific DNA sequences for particular diseases, those substances have some problem such as poor water solubility together with lack stability against heat and light.[2-5] It is well known that cyclodextrins (CyDs) work to increase water solubility and keep stability of heat and light when there is something interaction between organic molecule and CyD. Also there is another advantage because CyD has no toxicological properties for human being. Figure 1 shows the structure of $\beta-\mathrm{CyD}$, which is a cyclic compound composed of D-glucose units connected by $\alpha-1,4$ linkages. In this study, we tried to synthesize water soluble pyrene modified $\mathrm{CyD}$ derivative which will be able to intercalate DNA double strand because planer structure of pyrene unit is favorable to interact with DNA. [2] The synthetic strategy of modified CyDs is taking introduction of ethylendiamine or tetraethylenepentamine as linker which binds CyD and pyrene unit because those linkers increasing water solubility and preventing self inclusion of pyrene unit into CyD cavity. The synthetic pyrene modified $\beta$-CyDs are mono-6- (1pyrenebutylate-pentaaminotetraethyl-aminoethyl)-amino-6-deoxy$\beta$-CyD (I) and mono-6-(1-pyrenebutylate-pentaaminotetraethyl)6-deoxyl- $\beta$-CyD (II).

The UV-vis spectra, fluorescent spectra and circular dichroism (CD) spectra were measured when I and II interacted with single strand DNA (ssDNA, 40bp) of which sequence is ttaaaaatag gctatccett attaagtaaa atagggagtt and double strand DNA (dsDNA, 195bp) of which compliment sequence is ctgagttcca aatgtcccag ctgttttatg ctttgtctct gtttcccaga gaccetgagt gtggtctaga gttgggatga gcattggtct ctaatggttc tgaaataatt gtatattcct gcaaaaacat taagtctatt
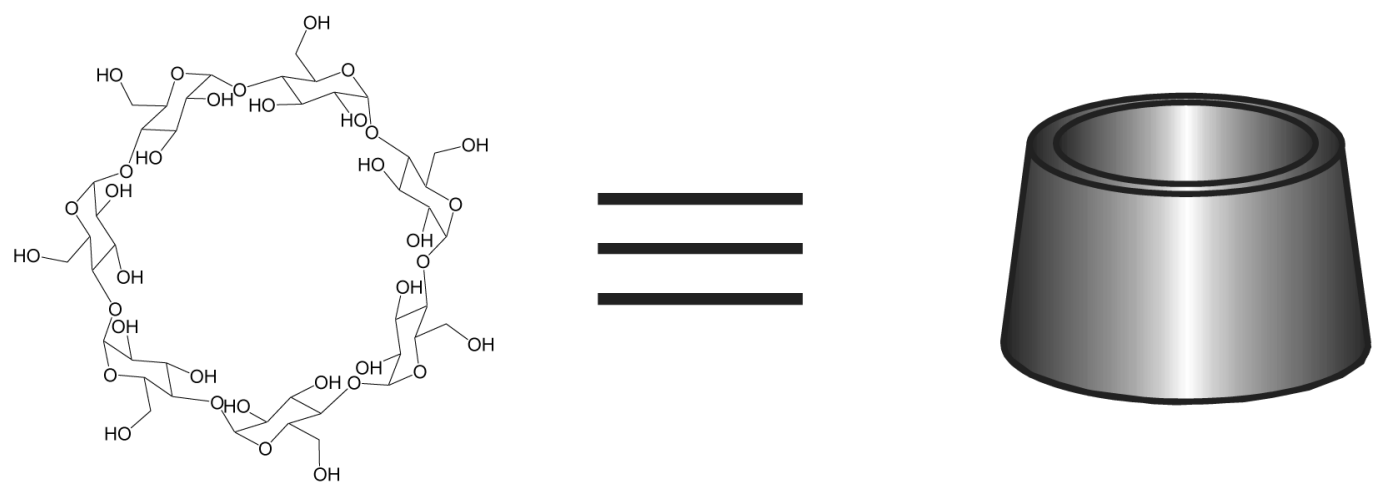

Figure 1 Structure of $\beta$-cyclodextrin. 
agaaaccagc taatttcatt ttgtcatttt tataggtaac atattctggt gcagg in aqueous solution. This sequence shows osteoporosis.

\section{EXPERIMENTAL}

Preparation of Mono-6-(1-pyrenebutylate-aminoethyl)-amino-6deoxy- $\beta$-CyD (I)

To solution of 1-pyrenebutylic acid $(0.1378 \mathrm{~g}, 0.4779 \mathrm{mmol})$ and 1-hydroxybenzotriazole (1-HOBt, $0.1294 \mathrm{~g}, 0.9576 \mathrm{mmol}$ ) in a mixture of dry-DMF $(50 \mathrm{ml})$ and pyridine $(50 \mathrm{ml})$, 1-ethyl-3(3-dimethylaminopropyl)carbodiimide (EDC, $0.1712 \mathrm{~g}, 0.8931$ mmol) was added at $-15^{\circ} \mathrm{C}$. The reaction mixture was cooled down at $-25^{\circ} \mathrm{C}$ and stirred for $2 \mathrm{hr}$ and then mono-6-(2aminoethyl)-amino-6-deoxy- $\beta$-CyD [6]（0.5053 g, $0.4293 \mathrm{mmol})$ was added. The reaction mixture was warmed up at room temperature and then stirred for 4days. The mixture was concentrated in vacuo which was treated with $300 \mathrm{ml}$ of acetone. The resulting precipitates were filtered and dried up to give crude product was obtained $(0.6219 \mathrm{~g})$. The crude product was treated with $100 \mathrm{ml}$ of water of which water soluble fraction was loaded on CM Sepahedx C-50 column chromatography $(250 \mathrm{~mm}$ x $55 \mathrm{~mm})$. After $1200 \mathrm{ml}$ of water was eluted and then $0.05 \%$ aqueous ammonia $(1000 \mathrm{ml})$ was eluded to obtain pure I fraction, which was collected and dried up in vacuo to give pure I $(0.2868 \mathrm{~g}, 0.1981 \mathrm{mmol}, 46.15 \%$ yield $)$. $\mathrm{R}_{\mathrm{f}}$ : 0.62 (propanol-water-ethyl acetate-ammonia ${ }_{\mathrm{aq}}(28 \%) \quad 5: 2: 3: 3$ by volume, TLC; silica gel $\left.60 \mathrm{~F}_{254}\right)$.

${ }^{1} \mathrm{H}$ NMR $\left(300 \mathrm{MHz}, \mathrm{D}_{2} \mathrm{O}\right): \delta=3.3-3.8\left(42 \mathrm{H}, \mathrm{m}, \mathrm{C}^{2} \mathrm{H}-\mathrm{C}^{6} \mathrm{H}\right.$ of CyD), 4.8-4.9 (7H, m, C ${ }^{1} \mathrm{H}$ of CyD), 7.3-8.3 (9H, m, aromatic-H of pyrene).

FAB-MS (m/z) 1469.

Preparation of Mono-6-(1-pyrenebutylate-pentaaminotetraethyl)6-deoxy- $\beta$-CyD（II）

To a solution of 1-pyrenebutylic acid $(0.2570 \mathrm{~g}, 0.8913 \mathrm{mmol})$ and $1-\mathrm{HOBt}(0.1314 \mathrm{~g}, 0.9724 \mathrm{mmol})$ in a mixture of dry-DMF $(50 \mathrm{ml})$ and pyridine $(50 \mathrm{ml}), \mathrm{EDC}(0.2028 \mathrm{~g}, 1.058 \mathrm{mmol})$ was added at $-15^{\circ} \mathrm{C}$. The reaction mixture was cooled down at $-25^{\circ} \mathrm{C}$ and stirred for $2 \mathrm{hr}$ and then mono-6-(pentaaminotetraethyl)-6deoxy- $\beta$-CyD [6] $(0.5060 \mathrm{~g}, 0.3874 \mathrm{mmol})$ was added. The reaction mixture was warmed up at room temperature and then stirred for 4days. The mixture was concentrated in vacuo which was treated with $300 \mathrm{ml}$ of acetone. The resulting precipitates were filtered and dried up to give crude product was obtained $(0.6219 \mathrm{~g})$. The crude product was treated with $100 \mathrm{ml}$ of water of which water soluble fraction was loaded on CM Sepahedx C-50 column chromatography $(250 \mathrm{~mm}$ x $55 \mathrm{~mm})$. After $1200 \mathrm{ml}$ of water was eluted and then $0.1 \%$ aqueous ammonia $(1000 \mathrm{ml})$ was eluded to obtain pure II fraction, which was collected and dried up in vacuo to give pure II $(0.1033 \mathrm{~g}, 0.06552 \mathrm{mmol}, 16.91 \%$ yield $) . \mathrm{R}_{\mathrm{f}}: 0.60$ (propanol-water-ethyl acetate-ammonia $a_{\mathrm{aq}}(28 \%)$ 5:2:3:3 by volume, TLC ; silica gel $60 \mathrm{~F}_{254}$ ).

$\mathrm{H}$ NMR $\left(300 \mathrm{MHz}, \mathrm{D}_{2} \mathrm{O}\right): \delta=3.3-3.7\left(42 \mathrm{H}, \mathrm{m}, \mathrm{C}^{2} \mathrm{H}-\mathrm{C}^{6} \mathrm{H}\right.$ of $\mathrm{CyD})$, 4.7-4.9 (7H, m, $\mathrm{C}^{1} \mathrm{H}$ of $\left.\mathrm{CyD}\right)$, 7.4-7.8 (9H, m, aromatic-H of pyrene).

FAB-MS (m/z) 1598 .

Measurement

UV-vis, Fluorescence and $\mathrm{CD}$ spectra were measured at $25^{\circ} \mathrm{C}$ using SHIMAZU-3600 Spectrophotometer, Perkin-Elmer LS 40B Fluorescence Spectrophotometer and JASCO J-720 Spectrophotometer, respectively. For the UV-vis measurement, water and phosphoric acid buffer ( $\mathrm{pH}$ 7.0) were used as solvent for the pyrene-modified $\beta$-CyDs and DNA. When DNA solution was added to the pyrene modified $\beta$-CyD solution $\left(1.0 \times 10^{-5} \mathrm{M}\right)$, the spectra change was recorded. For the fluorescence measurements, the excitation wavelength of the fluorescence spectra was $340 \mathrm{~nm}$ and excitation and emission slits were $5 \mathrm{~nm}$. Water and phosphoric acid buffer $(\mathrm{pH} 7.0)$ were used as solvent for the
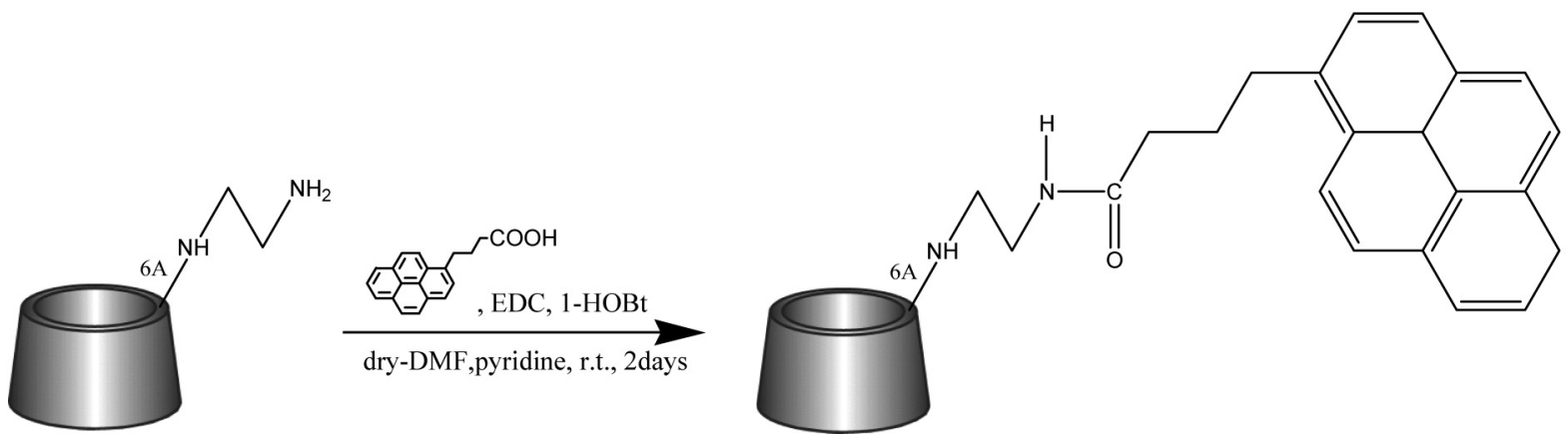

Scheme 1 Preparation of mono-6-(1-pyrenebutylate-aminoethyl)-amino-6-deoxy- $\beta$-CyD (I)
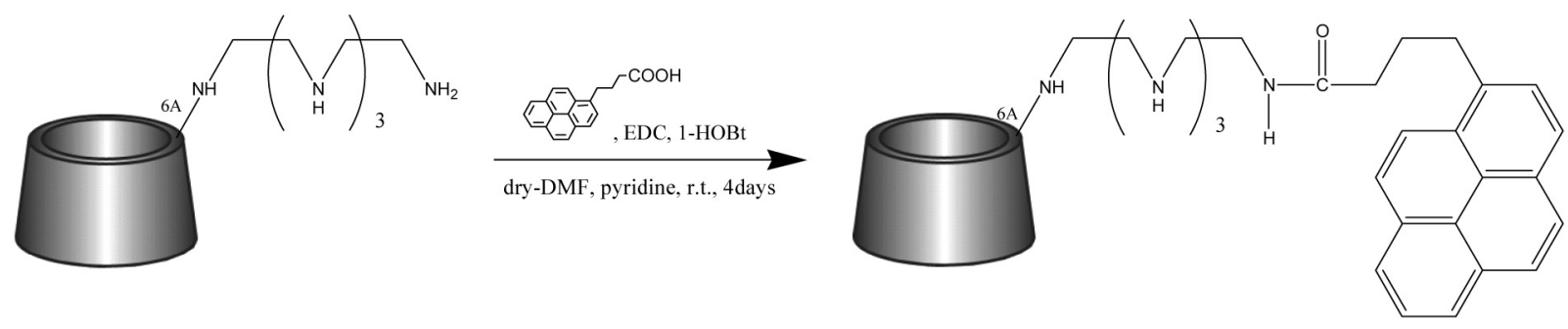

Scheme 2 Preparation of mono-6-(1-pyrenebutylate-pentaaminotetraethyl)-6-deoxy- $\beta$-CyD (II) 
$\beta$-CyDs and DNA. When DNA solution added to the pyrene modified $\beta$-CyD solution $\left(1.0 \times 10^{-7} \mathrm{M}\right)$, the spectra change was recorded. For the $\mathrm{CD}$ measurement, water were used as solvent for the II. When DNA solution was added to the II solution $(5.0 \mathrm{x}$ $\left.10^{-5} \mathrm{M}\right)$, the spectra change was recorded.

\section{RESULTS AND DISCUSSION}

Preparations of $\mathbf{I}$ and $\mathbf{I I}$.

Pyrene modified $\beta$-CyDs (I and II), where CyD and pyrene were linked by ethylenediamine and tetraethylene pentamine, respectively, have been made in the presence of EDC and 1-HOBt. The preparation method of I and II was shown in Schemes 1 and 2.

\section{Spectra of I with ssDNA and dsDNA}

The absorption and fluorescent spectra of $\mathbf{I}$ alone and with ss and dsDNA in aqueous solution or $0.1 \mathrm{M}$ phosphate buffer $(\mathrm{pH}$

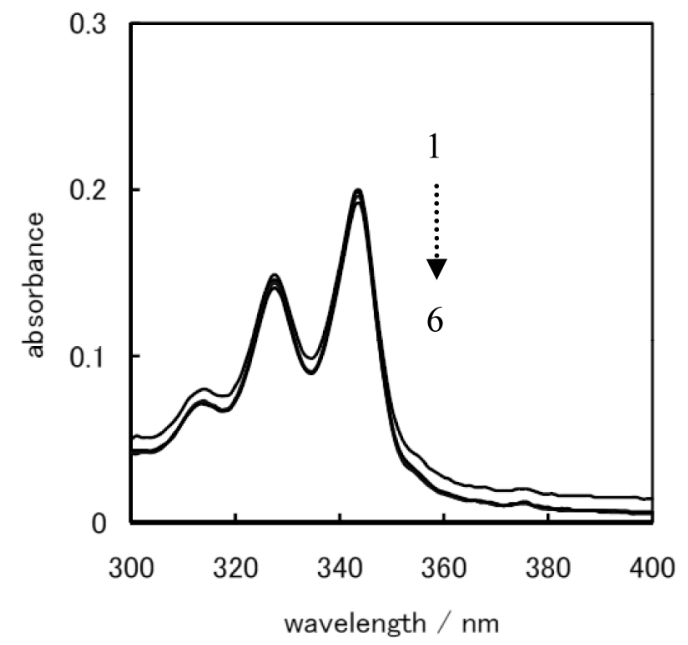

Figure $2 \mathrm{UV}$-vis spectra of $\mathbf{I}\left(1.0 \times 10^{-5} \mathrm{M}\right)$ at various concentration of ssDNA $\left(1 ; 0,2 ; 0.5 \times 10^{-7}, 3 ; 1.0 \times 10^{-7}, 4 ; 1.5 \times 10^{-7}, 5\right.$; $\left.2.0 \times 10^{-7}, 6 ; 2.5 \times 10^{-7} \mathrm{M}\right)$ in aqueous solution.

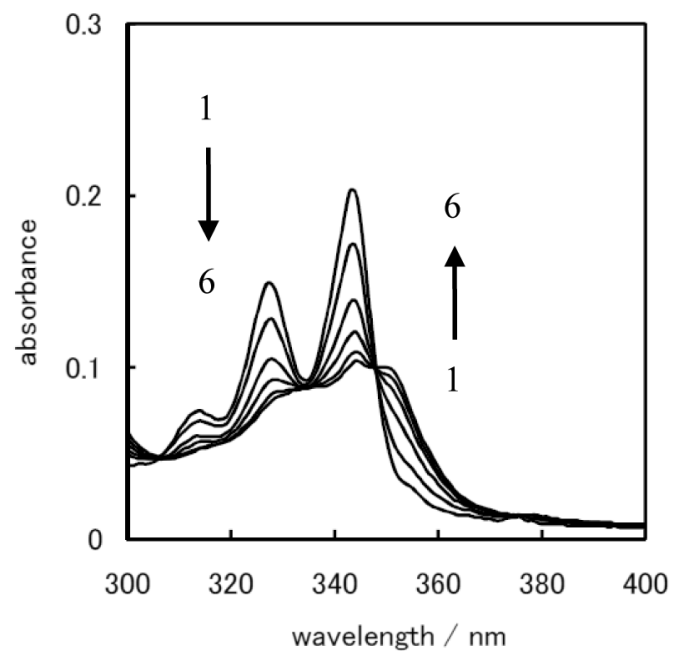

Figure 4 UV-vis spectra of $\mathbf{I}\left(1.0 \times 10^{-5} \mathrm{M}\right)$ at various concentration of dsDNA $\left(1 ; 0,2 ; 2.5 \times 10^{-8}, 3 ; 5.0 \times 10^{-8}, 4 ; 7.5 \times 10^{-8}, 5\right.$; $\left.1.0 \times 10^{-7}, 6 ; 1.25 \times 10^{-7} \mathrm{M}\right)$ in aqueous solution.
7.0) were recorded to investigate the interaction between $\mathbf{I}$ and ss and dsDNA.

Figures 2 and 3 show the absorption and fluorescent spectra of I alone and with ssDNA in aqueous solution. Although, the absorption spectrum of $\mathbf{I} \mathrm{w}$ as recognized between 220 to $360 \mathrm{~nm}$ region, the spectrum region between 220 to $300 \mathrm{~nm}$ goes over the spectrum derived from DNA, the peaks between 330 to $345 \mathrm{~nm}$ originated from pyrene were only reco ded. When ssDNA was added to the solution of $\mathbf{I}$, the absorption and fluorescent spectra were not changed, which means that pyrene unit of I might not interact with ssDNA.

Figures 4 and 5 show the absorption and fluorescent spectra of I alone and with dsDNA in aqueous solution. When dsDNA was added to the solution of $\mathbf{I}$, the absorption spectra were changed to strong decrease in peaks at $330 \mathrm{~nm}$ and $345 \mathrm{~nm}$ and increase in a peak at $350 \mathrm{~nm}$. An isosbestic point at $347 \mathrm{~nm}$ was observed. But, the fluorescent spectrum was not changed, when dsDNA was

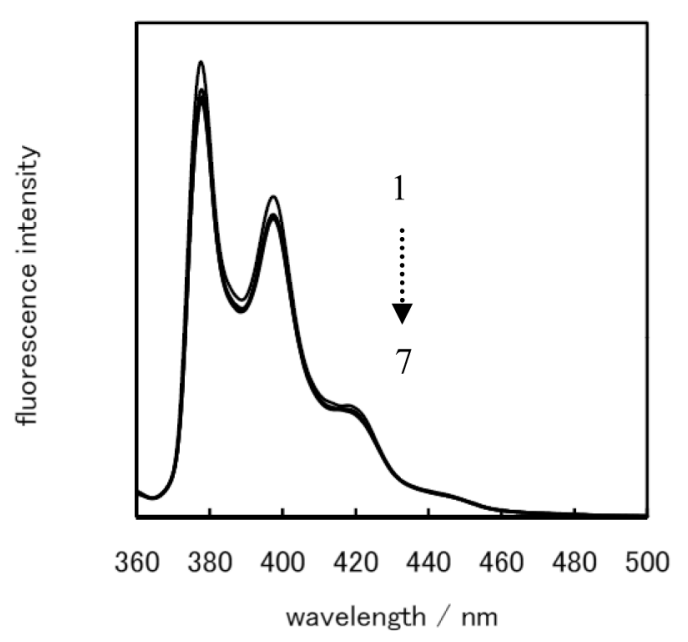

Figure 3 Fluorescent spectra of $\mathbf{I}\left(1.0 \times 10^{-7} \mathrm{M}\right)$ at various concentration of ssDNA $\left(1 ; 0,2 ; 5.0 \times 10^{-10}, 3 ; 1.0 \times 10^{-9}, 4 ; 1.5 \times\right.$ $\left.10^{-9}, 5 ; 2.0 \times 10^{-9}, 6 ; 2.5 \times 10^{-9}, 7 ; 5.0 \times 10^{-9} \mathrm{M}\right)$ in aqueous solution.

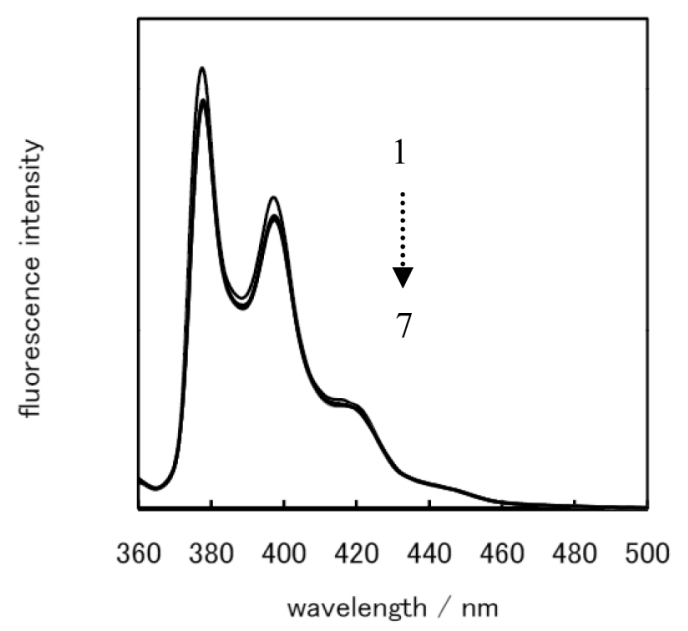

Figure 5 Fluorescent spectra of $\mathbf{I}\left(1.0 \times 10^{-7} \mathrm{M}\right)$ at various concentration of dsDNA $\left(1 ; 0,2 ; 1.0 \times 10^{-10}, 3 ; 2.0 \times 10^{-10}, 4 ; 3.0 \times\right.$ $\left.10^{-10}, 5 ; 4.0 \times 10^{-10}, 6 ; 5.0 \times 10^{-10}, 7 ; 1.0 \times 10^{-9} \mathrm{M}\right)$ in aqueous solution. 
added to the solution of $\mathbf{I}$. This suggested that there is something binding interaction between $\mathbf{I}$ and dsDNA.

When ssDNA or dsDNA was added to a solution of $0.1 \mathrm{M}$ phosphate buffer ( $\mathrm{pH}$ 7.0) containing I, the absorption and fluorescent spectra were almost not changed. It means that there is few interaction between $\mathbf{I}$ and ssDNA or dsDNA.

Spectra of II with ssDNA and dsDNA

The absorption and fluorescent spectra of II alone and with ss and dsDNA in aqueous solution or $0.1 \mathrm{M}$ phosphate buffer $(\mathrm{pH}$ 7.0) were recorded to investigate the interaction between II and ss and dsDNA.

Figure 6 shows absorption spectra of II in aqueous solution alone and with ssDNA, which indicates dramatically change of absorbance. An isosbestic point at $347 \mathrm{~nm}$ was observed, suggesting that there is something binding interaction between II and ssDNA. Also fluorescent spectra of II were changed in

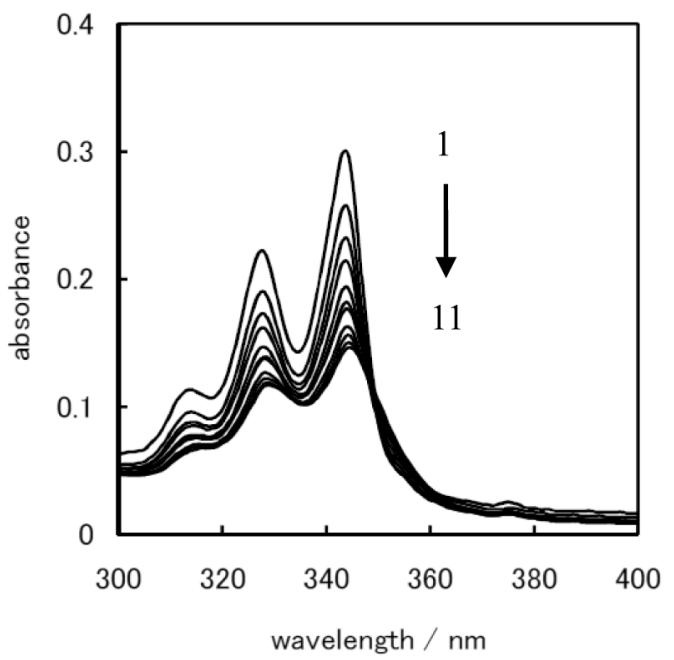

Figure 6 UV-vis spectra of II $\left(1.0 \times 10^{-5} \mathrm{M}\right)$ at various concentration of ssDNA $\left(1 ; 0,2 ; 0.5 \times 10^{-7}, 3 ; 1.0 \times 10^{-7}, 4 ; 1.5 \times 10^{-7}, 5\right.$; $2.0 \times 10^{-7}, 6 ; 2.5 \times 10^{-7}, 7 ; 3.0 \times 10^{-7}, 8 ; 3.5 \times 10^{-7}, 9 ; 4.0$ $\left.\mathrm{x} 10^{-7}, 10 ; 4.5 \times 10^{-7}, 11 ; 5.0 \times 10^{-7} \mathrm{M}\right)$ in aqueous solution.

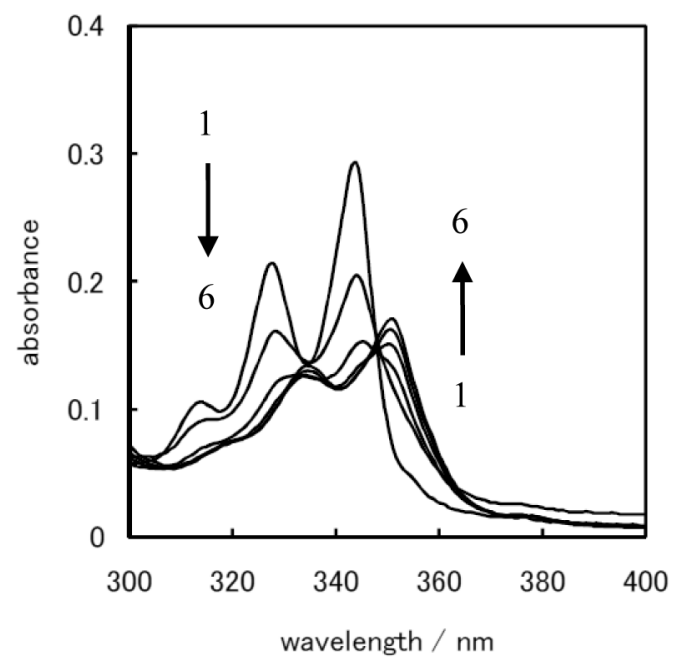

Figure 8 UV-vis spectra of II $\left(1.0 \times 10^{-5} \mathrm{M}\right)$ at various concentration of dsDNA $\left(1 ; 0,2 ; 2.5 \times 10^{-8}, 3 ; 5.0 \times 10^{-8}, 4 ; 7.5 \times 10^{-8}, 5\right.$; $\left.1.0 \times 10^{-7}, 6 ; 1.25 \times 10^{-7} \mathrm{M}\right)$ in aqueous solution. addition of ssDNA as shown in Figure 7. When ssDNA was added to the aqueous solution of II, the decrease of the intensity was recognized. The almost same phenomena were observed when dsDNA was added to the aqueous solution of II as shown in Figures 8 and 9, respectively.

The only difference is the magnitudes of change and decrease of absorption and fluorescent spectra, respectively. When ssDNA was used, the change and decrease magnitude was small. It suggested that the interaction between II and dsDNA was much stronger than that of ssDNA and II. It is well known the decrease and increase of the intensity of fluorescent spectra were depended on the high and lower polarities of surrounded environment for chromophore, respectively. [7-11] Both fluorescent intensities of II in addition of ss and dsDNA were decreased, which suggests that pyrene unit moves into the higher polarity environment than that of CyD cavity. It is just speculation of the movement of pyrene unit when ssDNA or dsDNA was added to the solution of

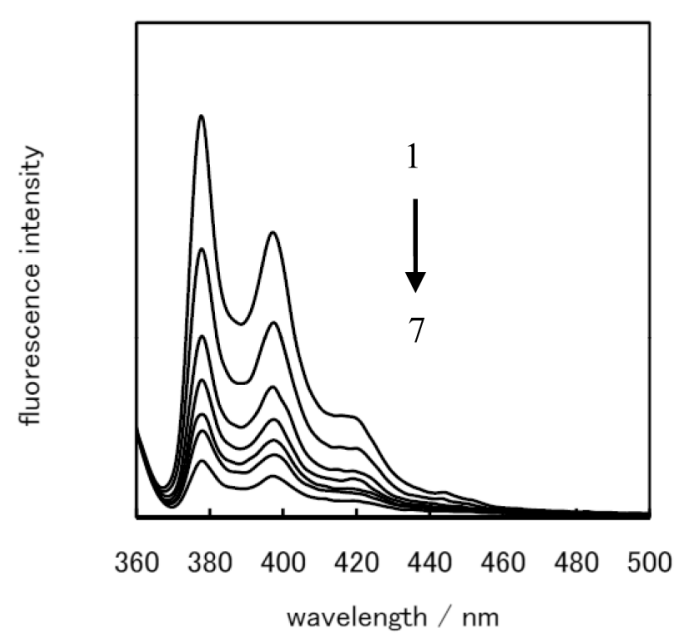

Figure 7 Fluorescent spectra of II $\left(1.0 \times 10^{-7} \mathrm{M}\right)$ at various concentration of ssDNA $\left(1 ; 0,2 ; 5.0 \times 10^{-10}, 3 ; 1.0 \times 10^{-9}, 4 ; 1.5 \times\right.$ $\left.10^{-9}, 5 ; 2.0 \times 10^{-9}, 6 ; 2.5 \times 10^{-9}, 7 ; 5.0 \times 10^{-9} \mathrm{M}\right)$ in aqueous solution.

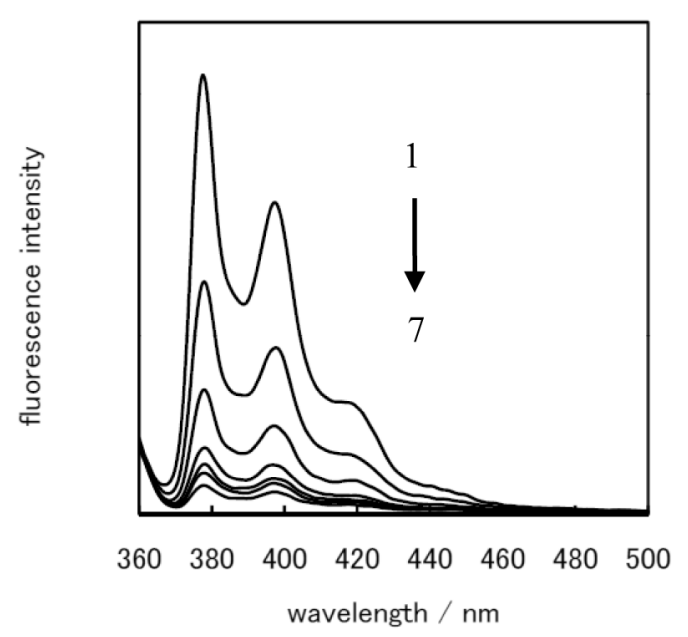

Figure 9 Fluorescent spectra of II $\left(1.0 \times 10^{-7} \mathrm{M}\right)$ at various concentration of dsDNA $\left(1 ; 0,2 ; 1.0 \times 10^{-10}, 3 ; 2.0 \times 10^{-10}, 4 ; 3.0 \times\right.$ $\left.10^{-10}, 5 ; 4.0 \times 10^{-10}, 6 ; 5.0 \times 10^{-10}, 7 ; 1.0 \times 10^{-9} \mathrm{M}\right)$ in aqueous solution. 


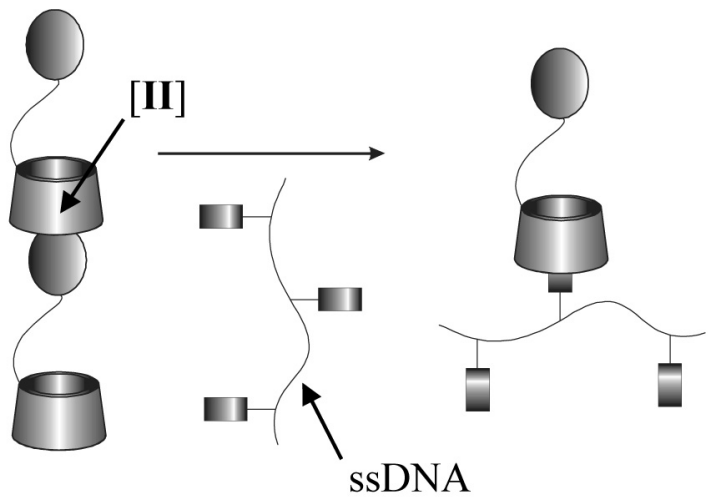

Scheme 3 Proposed an interaction between $\mathbf{I}$ and ssDNA in aqueous solution.

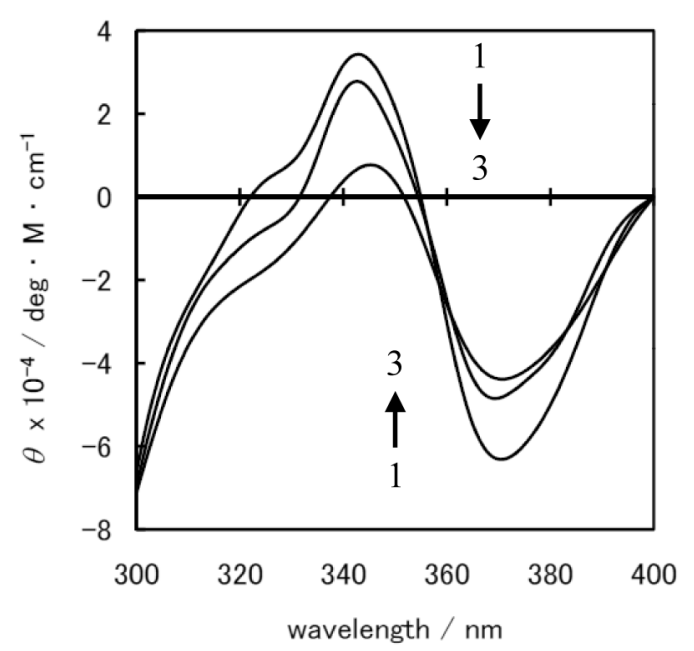

Figure $10 \mathrm{CD}$ spectra of II $\left(5.0 \times 10^{-5} \mathrm{M}\right)$ at various concentration of ssDNA $\left(1 ; 0,2 ; 2.5 \times 10^{-7}, 3 ; 6.25 \times 10^{-7} \mathrm{M}\right)$ in aqueous solution.

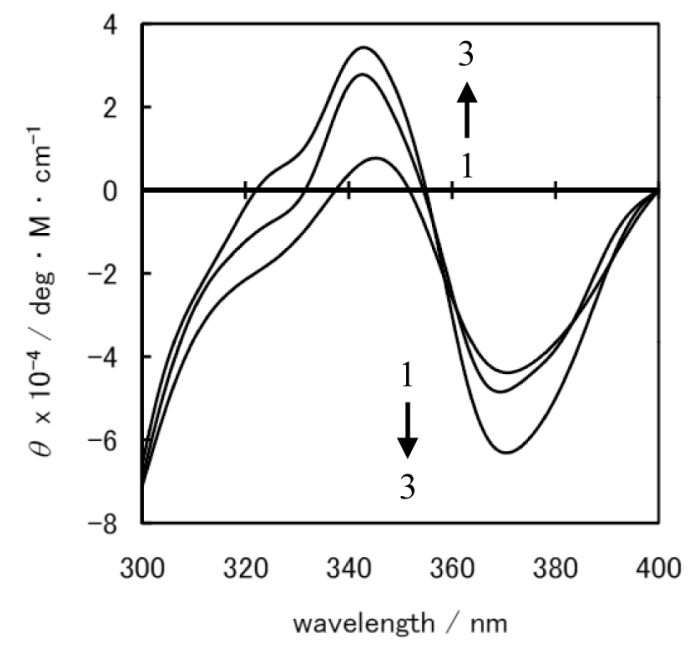

Figure $11 \mathrm{CD}$ spectra of II $\left(5.0 \times 10^{-5} \mathrm{M}\right)$ at various concentration of dsDNA $\left(1 ; 0,2 ; 5.0 \times 10^{-8}, 3 ; 1.25 \times 10^{-7} \mathrm{M}\right)$ in aqueous solution.

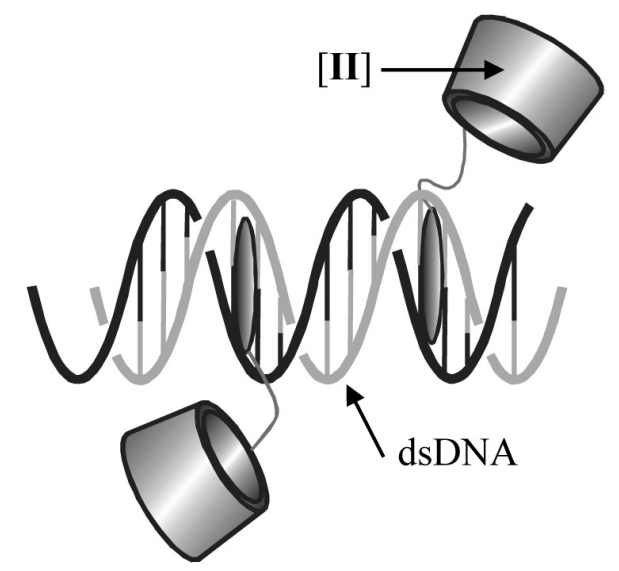

cheme 4 Model of intercaration based on II into dsDNA in aqueous solution.

II. It seems that II can be partially included in the cavity of another II where the intermolecular complexation came down in addition of ssDNA as shown in Scheme 3. Because a size of ssDNA is smaller molecule than that of dsDNA, ssDNA can be included in the CyD cavity. On the other hand, dsDNA is too larger molecule to be included in CyD cavity where II can intercalate into dsDNA as shown in Scheme 4.

When 0.1 M phosphate buffer ( $\mathrm{pH}$ 7.0) was used, the absorption and fluorescent spectra were almost not changed.

The CD spectra was recorded to investigate how movement of pyrene unit of II when ss or dsDNA was added. Figure 10 shows the CD spectra of II alone and with ssDNA. Like exciton coupling was observed, where the positive cotton effect at $340 \mathrm{~nm}$ was decresed and the negative cotton effect at $365 \mathrm{~nm}$ was decreased. It suggested that pyrene unit goes into the less chiral environment. On the other hand, the CD spectra of II alone shows positive cotton effect at $345 \mathrm{~nm}$ and negative cotton effect at $370 \mathrm{~nm}$, which were increased upon addition of dsDNA, as shown in Figure 11. It suggested that the pyrene unit goes into more chiral environment. It is cleary contrary phenomena in addition of ssDNA and dsDNA. Original cotton effects at around 340 and 370 $\mathrm{nm}$ were derived from the interaction between pyrene unit and CyD cavity because of its chirality, which means that decrease of cotton effect indicate pyrene unit moves far from the CyD cavity and increase of cotton effect indicates the pyrene unit move closely the CyD cavity. In conclusion, when ssDNA was added to the solution of II, the pyrene unit moves far from the CyD cavity. When dsDNA was added to the solution of II, the pyrene unit move far from the chiral CyD cavity which resulted in a formation of intercalative binding between II and dsDNA.

\section{CONCLUSION}

We succeeded in a synthesis of I and II in a high yield. Although these compounds in a structure are only different in linker parts, they showed different interactions for ss and ds DNA. We are now investigating in a development of detectable reagent using of CyDs and pyrene systen with sensitivity and selectivity.

\section{ACKNOWLEDGMENTS}

We thank Nipro Corporation for kind gifts of ssDNA, dsDNA, forward and reverse primers. 


\section{References}

[1] K. M. Applebaum, M. R. Karagas, D. J. Hunter, P. J. Catalano, S. H. Byler, S. Morris and H. H. Nelson, "Polymorphisms in Nucleotide Excision Repair Genes, Arsenic Exposure, and Non-Melanoma Skin Cancer in New Hampshire", Environ. Health. Perspect., 115, 8, (2007).

[2] L. Hernandez-Folgado, C. Schmuck, S. Tomic and I. Piantanida, "A novel pyrene-guanidiniocarbonyl-pyrrole cation efficiently differentiates between ds-DNA and dsRNA by two independent, sensitive spectroscopic methods", Bioorg. Med. Chem. Lett., 18, 2977-2981, (2008).

[3] M. Asakawa, K. Endo, K. Kobayashi, H. Toi and Y. Aoyama, "Enantioselectivity in the Interraction of Carf Thymus DNA with Acridine Derivatives Having an Amino Ester or Amino Alcohol Substituent", Bull. Chem. Soc. Jpn., 65, 2050-2055, (1992).

[4] L. Perez-Flores, A. J. Ruiz-Chica, J. G. Delcros, F. SanchezJimenez and F. J. Ramirez., "Intercalation and groove binding of an acridine - spermine conjugate on DNA sequences: an FT - Raman and UV - visible absorption study", J. Mol. Struct. 744-747, 699-704, (2005).

[5] X. Jiang, L. Shang, Z. Wang and S. Dong, "Spectrometric and voltammetric investigation of interaction of neutral red with calf thymus DNA: pH effect", Biophy. Chemist. 118, 42-50, (2005).

[6] H.-J. Schneider and F. Xiao, "Binding and catalysis with a metal-induced ternary complex of an ethylenediaminesubstituted cyclodextrin", J. Chem. Soc., Perkin Trans. 2, 387-391, (1992).

[7] R. Ostaszewski, E. Wilczynska and M. Wolszczak, "The Synthesis of a New Type of Anthracene DNA Intercalator", Bioorg. Med. Chem. Lett., 8 2995-2996 (1998).

[8] M. Narita, J. Itoh, T. Kikuchi and F. Hamada, "A High Sensitivity Fluorescent Chemo-sensory System Based on $\beta$-Cyclodextrin Dimer Modified with Dansyl Moieties", J. Incl. Phenom, Macrocyclic Chem., 42, 107-114, (2002).

[9] F. Hamada, K. Ishikawa and Y. Higuchi, "Strong Binding Between Acidic Guests and Fluorescein Modified $\gamma$ Cyclodextrin via Hydrogen Bonding" J. Incl. Phenom, Mol. Recognit. Chem., 25, 283-294, (1996).

[10] M. Narita, S. Mima, N. Ogawa and F. Hamada, "Selective Fluorescent Molecular Sensing by Bis Dansyl-Modified $\gamma$ Cyclodextrin Dimer", Anal. Sci., 16, 865, (2000).

[11] M. Narita, N. Ogawa and F. Hamada, "Fluorescence Molecular Sensing for Endocrine-disrupting Chemicals and Their Analogues Based on Dansyl or Anthranilate Modified $\beta$ - and $\gamma$-Cyclodextrins", Anal. Sci., 16, 37, (2000) 